\title{
The Influence of COVID-19 on Indonesian Investment
}

\author{
Jeliastiva \\ jeliastiva22@gmail.com \\ Accounting Department, Faculty of Economics and Business, University of \\ Muhammadiyah Makassar, Indonesia \\ Received: August 2, 2020 \\ Received in revised: August 10, 2020 \\ Accepted: August 12, 2020
}

\begin{abstract}
The COVID-19 outbreak has had a serious impact on almost all countries in the world, including Indonesia. In response to this case, various policies began to emerge. Starting from the implementation of work from home, social distancing and physical distancing, until the implementation of large-scale social restrictions (PSBB). Overseas investors are busy focusing their finances on the needs of their respective countries to fight the virus. Domestic investment (PMDN) is also predicted to experience a slowdown. The social distancing policy resulted in the community not being able to run the economic system well, especially in the Indonesian investment sector so that the perokoniman namely investment in Indonesia decreased and there were some delays in investment by other countries in Indonesia.
\end{abstract}

Keywords: Covid-19, Investment, Social Distancing

\section{Introduction}

A pandemic is the scale of the spread of disease that occurs globally throughout the world (Kelly, 2011). The corona virus is a large family of viruses that can cause disease in animals or humans (WHO: 2020). In humans, corona is known to cause respiratory infections ranging from the common cold to more severe diseases such as Middle East Respiratory Syndrome (MERS) (Ren, Gao \& Chen, 2020), and Severe Acute Respiratory Syndrme (SARS). The most common symptoms of COVID-19 are fever, fatigue and dry cough. Some patients may experience aches and pains, nasal congestion, runny nose, sore throat or diarrhea. These symptoms are mild and occur gradually. The COVID-19 corona virus spreads person to person through small droplets from the nose or mouth that are spread when a person coughs or exhales. These droplets then fall on objects touched by other people (WHO: 2020).

The COVID-19 outbreak was first detected in Wuhan City, Hubei Province, China in December 2019, and was declared a pandemic by the World Health Organization (WHO) on March 11, 2020. As of April 23, 2020, more than 2,000,000 cases of COVID-19 has been reported in more than 210 countries and regions, resulting in more than 195,755 people died and more than 781,109 people recovered (WHO: 2020).

The COVID-19 outbreak has had a serious impact on almost all countries in the world, including Indonesia. The effect is not only in one area, but in almost all existing activities (Alon et al, 2020; Chetty et al, 2020; Guerrieri et al, 2020; Nicola et al, 2020; Ozili \& Arun, 2020). One aspect of concern in the midst of the Coronavirus outbreak is investment. The existence of various restrictions in a country certainly has an impact on economic activity. In $\mathrm{KBBI}$, investment is an investment of money or capital in a company or project for the purpose of obtaining profit. Investment is an investment for one or more assets that are 
owned and usually have a long term with the hope of getting benefits in the future (Sunariyah, 2003: 4).

In response to this case, various policies began to appear. Starting from the implementation of work from home, social distancing and physical distancing, until the implementation of largescale social restrictions (PSBB). Of course this will have an impact on the economy in Indonesia. The government and society must be prepared for what will happen if the case of the spread of this virus continues. The impact of the spread of the corona virus occurred in various fields, both in the real sector and the stock market. And what is felt most heavily is the global economy in Indonesia, where growth is slowing down.

The government is opening wide doors for foreign investment in Indonesia. This is done by the government because foreign investment provides great benefits such as getting a lot of new capital, opening new jobs, progress in certain fields, increasing state income and obtaining territorial protection.

Based on the background description above, the author is interested in making a scientific paper entitled "The Effects of the Spread of COVID-19 on Indonesian Investment" which aims to provide information that the presence of COVID-19 has an impact on Indonesian investment.

\section{The spread of the Corona Virus in Indonesia}

The corona virus (SARS-CoV-2 / COVID-19, previously known as 2019-nCoV) is a type of virus that causes diseases such as the common cold, MERS, SARS, and other potentially deadly respiratory diseases. Although it can have serious consequences, preventive measures can help protect a person's health from the coronavirus, both in the community, at home and while caring for people who are sick. The virus first appeared in Wuhan, a city in China. According to news circulating about the source of the emergence of this virus, from food to poultry.

This virus spreads quickly and has spread to several countries, including Indonesia. One of the causes of the corona virus spreading easily in Indonesia is because Indonesia is a country with a tourism sector. The tourism sector is one of the factors that plays an important role in Indonesia's economic growth and has the second largest foreign exchange contribution in Indonesia after oil palm exports. The tourism sector has a short-term and long-term impact on the Indonesian economy. The short-term impact can be felt directly, while the long-term impact can be seen by increasing national income, but with the presence of COVID-19 everything is no longer the same.

In Indonesia, the spread of this virus began on March 2, 2020, allegedly starting from an Indonesian citizen who had direct contact with a foreign national who came from Japan. This has been announced by Mr. President Jokowi. Over time, the spread of covid-19 has increased significantly. This can be seen from the following data.

Based on data updated by the Task Force for the Acceleration of Handling of COVID-19 at 15.40 WIB, Thursday, April 2, 2020, 113 new positive cases were added. This addition brings the total number of positive cases of COVID-19 in Indonesia to 1,790 patients. A total of 1,508 positive COVID-19 patients in Indonesia are currently undergoing treatment. Meanwhile, the number of COVID-19 patients who have recovered has increased to 112 . However, the death rate for positive COVID-19 patients in Indonesia has also increased to 170 people.

\section{The Influence of COVID-19 on Indonesian Investment}

Copyright (C) 2020, Journal of Asian Multicultural Research for Economy and Management Study, Under the license CC BY-SA 4.0 
Indonesia has been hit hard enough by the spread of the Corona virus. Not only human health, this virus also disrupts economic health around the world. It is estimated that Indonesia's economic growth in the worst scenario could be minus 0.4 percent. This occurs because current conditions will have an impact on decreasing household consumption, which is estimated at 3.2 percent to 1.2 percent. More than that, investment will also decline sharply. Previously, the government was quite optimistic that investment would grow by six percent. However, with the presence of COVID-19, it is predicted that investment will fall to a level of one percent or at worst it could reach minus four percent (Intan, 2020).

The decline in investment value will be very noticeable when viewed from the trade relations involving the COVID-19 epicenter countries, one of which is the PRC. The existence of restrictions or lockdowns has affected trading activities with significant losses. This activity includes all business activities related to the supply of materials directly related to China, both export and import.

With the spread of COVID-19 that is increasingly widespread, foreign investors are threatened with delay, such as Indonesia, which is one of the countries that receives quite a lot of investment flows from China, the country of origin of COVID-19. Throughout 2019, China ranked second in the list of countries with the most investment in Indonesia with US \$ 4.74 billion consisting of 2,130 investment projects. From the trade side, Indonesia is still in deficit with China worth US \$ 16.9 billion from the total trade value of US \$ 72.8 billion throughout 2019. With such investment and trade conditions, the impact of COVID-19 on Indonesia will be quite significant, especially on economic growth.

The impact of COVID-19 has delayed investment from China. The COVID-19 outbreak has hampered the mobilization of China's population so that many investors find it difficult to continue their investment. It is not possible to predict the potential losses from the delay in investment from China. However, investments from other countries, such as the United States, are still running smoothly.

In times of the corona pandemic like today, it is predicted that foreign investors are busy to focus their finances on the needs of their respective countries to fight this virus. Domestic investment (PMDN) is also predicted to experience a slowdown. This is also happening because domestic investors are shifting their financial priorities to basic needs to protect themselves during this corona pandemic. Countries such as China, the United States and European countries are still struggling to resolve the corona virus problem in their respective countries so that they have not had time to return their main focus to the world of investment, especially in Indonesia.

For the projections for the second quarter, in the face of this corona pandemic, BKPN has prepared a simulation of investment realization with three levels, namely levels of optimism, moderate and also pessimism to face the worst possibility. In addition, with an increase in investment, there will certainly be an increase in employment which will also increase.

Even though it was hit by the corona pandemic, the state of Indonesia's investment in the first quarter of this year was not too disappointing, so there is still great hope for investors to continue investing their money in Indonesia and get benefits later. So for people who are investors, there are still strong reasons to keep investing their money in several company sectors that are still running during this corona pandemic.

It is predicted that the investment impact will reach hundreds of trillions. The Institute for Development of Economics and Finance (INDEF) predicts that there is a potential loss of investment value of IDR 127 trillion due to the outbreak of COVID-19. This is not without

Copyright $@$ (2020, Journal of Asian Multicultural Research for Economy and Management Study, Under the license CC BY-SA 4.0 
reason, considering that one of the contributing factors is the prospect of increasingly depressed economic activity and growth. This was confirmed by the government which stated that every $1 \%$ decline in the economic value of PRC would have an impact on the Indonesian economy by $0.3 \%$. Seeing the situation that continues to develop, it is not impossible that the PRC economy can decline to the level of 5\% in 2020.

\section{Government Policies in Overcoming the Effects of COVID-19 on Indonesian Investment}

As for the first step taken by considering the corona virus scenario will end in the short term, the government through Bank Indonesia (BI) and the Financial Services Authority (OJK) maintains financial market stability without causing excessive panic for businesses and the public. The second step taken by the government is to issue a stimulus in the form of a policy package.

The current condition will have an impact on decreasing household consumption, which is estimated at 3.2 percent to 1.2 percent. More than that, investment will also decline sharply. Previously, the government was quite optimistic that investment would grow by six percent. However, with the presence of COVID-19, it is predicted that investment will fall to a level of one percent or at worst it could reach minus four percent.

So far, several steps have been taken to anticipate the impact of this COVID-19, including lowering BI's benchmark interest rate twice. BI coordinates with the government to carry out aspects related to monetary stability and monetary stimulus in which BI has lowered its interest rate twice so that the $\mathrm{BI}$ interest rate is 4.5 percent to release the burden on the business world. Second, BI continues to stabilize the rupiah exchange rate by intervening in the spot market, domestic non-delivery forward, as well as purchasing SBN from the secondary market.

There are plans to revise Indonesia's investment targets this year due to the corona virus (COVID-19) pandemic, which is considered to have an impact on investment in Indonesia. Where the initial target for 2020 investment is IDR 886 trillion. If by May 2020 the COVID19 pandemic is not over, BKPM will revise its investment target to IDR 850 trillion. That target could fall further depending on how long the pandemic lasts. If by July 2020 the pandemic is not over, BKPM will revise its investment target again to only IDR 817 trillion.

In addition, three scenarios have been prepared to achieve the investment realization target in 2020 , amid the spread of the corona virus outbreak. The three scenarios are simulation of investment realization scenario, optimism, moderate and pessimistic, although they do not explain in detail. In addition, by continuing to make efforts to convince investors, they are still interested in investing in Indonesia. One of them is the way to shorten the regulations which are constraining or difficult for investors and will also facilitate investors' permission from the import side.

Then, by changing the pattern that has been waiting for investment to come to "pick the ball" and by visiting investors who have not realized their investment and accompanying them until they realize their investment, reassuring investors regarding the government's efforts to maintain economic stability amid this outbreak. There are many ways that can be done to convince entrepreneurs or investors. Moreover, the government has cut short various things that hinder investment realization. By continuing to communicate with investors so they don't run away.

To be able to increase investment, the government must accelerate epidemic control nationally. So as to restore market confidence in domestic market demand, business climate

Copyright (C) 2020, Journal of Asian Multicultural Research for Economy and Management Study, Under the license CC BY-SA 4.0 
and national investment climate. At the same time, the Government must ensure that all policy reform agendas to improve the business climate and investment at the national and regional levels are consistent and implemented in parallel with the handling of the epidemic.

There are 3 things that are key to achieving investment in the midst of the corona pandemic, namely; (1) Since there is already an existing investment whose progress is around $50 \%$ to $60 \%$, all that has to be done is to encourage it, (2) Combing a number of projects that have stalled (stalled investment that has already been invested around Rp 200 trillion). 3. Changing the investment pattern where previously investors had to be busy arranging business permits now BKPM has come to solve various problems.

The problem is then sought for a solution. Strategies that must be carried out by the investor community, including investment managers and (possibly) regulators in the short term (temporarily) need to be carried out with the cooperation of all parties, among others; (1) Mutual funds should flexibly adjust their price from marked to market to fair value for stocks or bonds that are considered the most conservative. Thus reducing the amount of decline in net asset value, (2) Mutual fund investors (institutions including banks) should not sell mutual funds on a large scale to reduce pressure on the market, (3) We recommend that bond investors, especially banking, insurance, pension funds and managers investment does not necessarily sell its bonds considering that the bond issuer still pays bond interest, (4) If needed, the investment manager can take the initiative and propose the formation of a fund that can cover capital market investment in banking thereby reducing the risk of asset decline, (5) If a policy can be made The accounting allows institutions not to book stock prices, bond securities and mutual funds marked to market. At least for 2020, to reduce the admission of unintentional losses (force majeure).

Thus, institutional investors who accidentally face the risk of impairment will be helped to stabilize the value of their assets in order to maintain the confidence of both local and foreign investors. It should be understood, though, that the decline in economic or industrial performance in Indonesia will not be too large, say around 3 to 6 months from March 2020, meaning that there is a moment of benefit received by the government and industry in the period January 2020 to March 2020 and in the period September 2020 to December 2020.

This can be seen in stocks whose companies have a positive ReOI with or without RNOA growth. What needs to be realized, maintaining the stability of the country's economy and industrial growth in order to remain good is a shared responsibility, it cannot be borne by the government alone. This of course must be assisted by all parties, both government-owned enterprises (state and regional) as well as private parties or related regulators as well as researchers at universities (Corporate, Government and University).

These steps can be taken while waiting for the COVID-19 to subside. Thus, the investment climate in Indonesia will soon improve and gain the trust of both local and foreign parties. Of course, the target is for the rupiah to strengthen again as soon as possible, before the end of September 2020. On the other hand, the Corona virus not only has a negative impact, but can also have a positive impact on the Indonesian economy. One of them is the opening of new export market opportunities apart from China. In addition, the opportunity to strengthen the domestic economy can also be realized because the government will prioritize and strengthen domestic purchasing power rather than taking profits from abroad. This condition can also be used as a correction so that investment can stabilize even though the global economy is being shaken. The impact of the corona can also have a positive impact on industry and investment in the country, especially in Batam as a free trade area and Batam free port. With the

Copyright (C) 2020, Journal of Asian Multicultural Research for Economy and Management Study, Under the license CC BY-SA 4.0 
outbreak of corona in China, and in several countries, there are opportunities for investors to choose to relocate their industries to a number of countries, including Indonesia.

\section{Conclusion}

Based on the results of the discussion about the corona (COVID-19) "The Effect of the Spread of COVID-19 on Indonesian Investment", it can be concluded that the spread of COVID-19 in Indonesia is always increasing every day. The social distancing policy resulted in the community not being able to run the economic system properly, especially in the Indonesian investment sector so that the perokoniman, namely investment in Indonesia, decreased and there were several delays in investment by other countries in Indonesia. There are three scenarios to achieve the investment realization target in 2020, amid the spread of the corona virus outbreak. The three scenarios are simulation of investment realization scenario, optimism, moderation and pessimism, BI will also continue to make efforts to convince investors to keep their interest in investing in Indonesia. One of them is the way to shorten the rules that are constraining conditions or in nature. as well as troublesome for investors. BKPM will also facilitate investor permits from the import side and add that through the command center formed by BKPM, namely the Operations Command Center and Investment Escort or the KOPI Center, BKPM will also change the pattern that has been waiting for investment to come to "pick the ball". BKPM will visit investors who have not realized their investment and accompany them until they realize their investment. So it is hoped that the steps that will be taken can reduce the impact of Covid-19 on investment in Indonesia.

\section{References}

Alon, T. M., Doepke, M., Olmstead-Rumsey, J., \& Tertilt, M. (2020). The impact of COVID19 on gender equality (No. w26947). National Bureau of Economic Research.

Chetty, R., Friedman, J. N., Hendren, N., \& Stepner, M. (2020). How did covid-19 and stabilization policies affect spending and employment? a new real-time economic tracker based on private sector data (No. w27431). National Bureau of Economic Research.

Guerrieri, V., Lorenzoni, G., Straub, L., \& Werning, I. (2020). Macroeconomic Implications of COVID-19: Can Negative Supply Shocks Cause Demand Shortages? (No. w26918). National Bureau of Economic Research.

Intan, G. (2020). Menkeu: Dampak Covid-19, Pertumbuhan Ekonomi Indonesia 2020 bisa Minus 0,4 persen. In VOA Indonesia. https://www.voaindonesia.com/a/menkeudampak-covid-19-pertumbuhan-ekonomi-indonesia-2020-bisa-minus-0-4persen/5355838.html

Kelly, H. (2011). The classical definition of a pandemic is not elusive. Bulletin of the World Health Organization, 89, 540-541.

Nicola, M., Alsafi, Z., Sohrabi, C., Kerwan, A., Al-Jabir, A., Iosifidis, C., ... \& Agha, R. (2020). The socio-economic implications of the coronavirus pandemic (COVID-19): A review. International journal of surgery (London, England), 78, 185.

Ozili, P. K., \& Arun, T. (2020). Spillover of COVID-19: impact on the Global Economy. Available at SSRN 3562570.

Ren, S. Y., Gao, R. D., \& Chen, Y. L. (2020). Fear can be more harmful than the severe acute respiratory syndrome coronavirus 2 in controlling the corona virus disease 2019 epidemic. World journal of clinical cases, 8(4), 652.

Copyright (C) 2020, Journal of Asian Multicultural Research for Economy and Management Study, Under the license CC BY-SA 4.0 